\title{
Administrasi Kurikulum Sekolah
}

\author{
Universitas Negeri Padang \\ Fakultas Pariwisata dan Perhotelan \\ Fitri Anjelya \\ E-mail : anjelyafitri@gmail.com
}

\begin{abstract}
Artikel ini berisi tentang pengertian administrasi kurikulum yang berarti seluruhproses kegiatan yang direncanakan dan sun gguh-sungguh untuk membantu, dan mengarahkan serta menumbuhkan situasi pembelajaran agar berjalan secara efisien untuk mencapai tujuan pendidikan yang di tentukan. Peran guru dalam administrasi kurikulum adalah sebgai pelaksana,adaptor,pengembang , dan peneliti. Artikel ini diharapkan dapat bermanfaat untuk mengorganisir pembelajran tentang administrasi kuri kulum .
\end{abstract}

\section{Kata kunci-Administrasi Kuri Kulum}

\section{Pendahuluan}

Pada dasarnya kurikulum merupakan suatu sistem yang terdiri dari beberapa komponen. Komponen-komponen kurikulum suatu lembaga pendidikan dapat diidentifikasi dengan cara mengkaji suatu kurikulum lembaga pendidikan itu. Dari buku tersebut kita dapat mengetahui pengertian dan dimensi kurikulum serta fungsi dan peranan suatu komponen kurikulum terhadap komponen kurikulum yang lain.

Kurikulum berfungsi sebagai pedoman dalam pelaksanaan kegiatan pendidikan di sekolah bagi pihak-pihak yang terkait, baim secara langsung maupun tidak langsung, seperti pihak guru, kepala sekolah, pengawas, orangtua, masyarakat dan pihak siswa itu sendiri. Selain sebagai pedoman, bagi siswa kurikulum memiliki enam fungsi, yaitu: fungsi penyesuaian, fungsi pengintegrasian, fungsi diferensiasi, fungsi persiapan, fungsi pemilihan, dan fungsi diagnostik. Salah satu aspek yang mempengaruhi keberhasilan kurikulum adalah pemberdayaan bidang pengelolaan kurikulum tersebut.

Tujan dari penulisan artikel administrasi kurikulum ini adalah untuk menjelaskan proses administrasi kurikulum dimana tahapnya dimaulai dari tahap perencanaan. Selainmenjelaskan proses administrasi kurikulum disini juaga terdapat peran guru dalam administrasi kurikulum. Jika kurikulum terencana dan terlaksana dengan baik maka pendidikan di Indonesia juga akan terlaksana dengan baik juga.

Pelaksanaan administrasi yang baik dari segi perencanaan hingga pelaksanaan kontrol dan pengawasan yang baik akan mempermudah tercapainya tujuan pendidikan. Namun pada kenyataannya masih banyak terdapat kegiatan administrasi yang tidak terlaksana dengan baik. Maka untuk itu, dengan adanya artikel ini penulis berharap dapat memberikan penjelasan mengenai pengertian, proses serta peran guru dalam administrasi kurikulum agar dapat diterapkan oleh pembaca sehingga administrasi kurikulum dapat terlaksana dengan baik.

\section{Metode Penelitian}

Metode penelitian adalah strategi umum yang digunakan dalam pengumpulan data, analisis data dan penarikan kesimpulan guna menjawab permasalah yang ada dalam penelitian.Artikel ini disusun menggunakan metode Systematic Literature Review (SLR), yaitu dengan mengumpulkan bahan-bahan kajian terlebih dahulu terkait pengertian administrasi kurikulum, proses serta peran guru dalam administrasi kurikulum baik berupa buku, artikel, jurnal, dan sumber lainnya.

\section{KaJian TeORI dAN PEMbahasan}

\section{A. Pengertian Administrasi Kurikulum}

Administrasi adalah subsistem dari organisasi itu sendiri yang unsur-unsurnya terdiri dari unsur organisasi yaitu tujuan, orang, sumber, dan waktu (Daryanto, 2011)..Menurut(Suryosubroto, 2004), kurikulum adalah segala pengalaman pendidikan yang diberikan oleh sekolah kepada seluruh anak didiknya, baik dilakukan di dalam sekolah maupun diluar sekolah. Pengalaman anak didik disekolah dapat diperoleh melalui berbagai kegiatan pendidikan antara lain : mengikuti pelajaran di kelas, praktik keterampilan, latihan-latihan olah raga dan kesenian dan kegiatan karya wisata atau praktik dalam laboratorium di sekolah.

Kurikulum berfungsi sebagai alat untuk pencapaian tujuan pendidikan, apabila tujuan pendidikan berubah maka maka secara otomatis kurikulum juga harus dirubah.Bagi anak kurikulum berguna sebagai alat untuk mengembangkan segenap potensi-potensi yang dimilikinya ke arah yang lebih baik di bawah bimbingan guru di sekolah. Bagi guru kurikulum berfungsi sebagai pedoman dan acuan dalam penyelenggaraan pembelajaran di sekolah Administrasi kurikulum dalam lembaga pendidikan merupakan seluruh proses kegiatan yang direncanakan dan diusahakan secara sengaja dan bersungguh-sungguh serta pembinaan secara continue terhadap situasi belajar mengajar secara efektif dan 
efisien demi membantu tercapainya tujuan pendidikan yang telah ditetapkan (Afriyansyah, 2019).

Jadi dapat disimpukan kurikulum adalah seperangkat rencana pembelajaran yang dirancang oleh pemerintah tingkat pusat yang bertujuan sebagai pedoman dalam kegiatan pembelajaran untuk mencapai tujuan pendidikan nasional.Kurikulum selalu mengalami perubahan sesuai dengan perkembangan zaman.Administrasi kurikulum merupakan seluruh proses kegiatan yang direncanakan dan diusahakan secara bersungguh-sungguh terhadap situasi belajar mengajar yang efektif dan efisien demi membantu tercapainya tujuan pendidikan yang telah ditetapkan. Dalam proses pendidikan perlu dilaksanakan administrasi kurikulum agar perencanaan, pelaksanaan, dan evaluasi kurikulum berjalan lebih efektif, efisien, dan optimal dalam memberdayakan berbagai sumber belajar, pengalaman belajar, maupun komponen kurikulum.

\section{B. Proses Administrasi Pendidikan}

\section{1) Perencanaan}

Perencanaan kurikulum sebagian besar dilaksanakan dan ditentukan oleh Departemen Pendidikan Nasional ditingkat pusat.Ini berarti bahwa ditingkat daerah dan sekolah tidak ada perencanaan kurikulum.Pada tahap perencanaan harus mencangkup beberapa hal yaitu:

\section{a) Menentukan Tujuan}

Pada tahap perencanaan ini kita terlebih dahulu harus menentukan tujuan dari kurikulum itu sendiri.Dimana tujuan kurikulum adalah sebagai pedoman dalam kegiatan pembelajaran untuk mencapai tujuan pendidikan nasional. Untuk dapat menetahui tujuan dari kurikulum ini kita harus menganalilis terlebih dahulu masalah apa yang terjadi dengan kurikulum sebelumnya, dan apa kelemahannya.kita juga menganalisis seberapa besar kebuhutuhan untuk mengubah kurikulum yang telah diterapkan terlebih dahulu.

\section{b) Menentukan Langkah dan Strategi Untuk Mencapai Tujuan Kurikulum}

Setelah menentukan tujuan dari perubahan kurikulum ini kita selanjutnya harus menentukan langkah dan strategi perubuhan kurikulum agar dapat mencapai tujuan kurikulum.Pada tahap ini kita harus terlebih dahulu memproritaskan perubuhan yang didasarkan dengan tujuan adanya perubahan kurikulum itu sendiri.Strategi yang kita buat harus lebih baik dari strategi sebelumnya, dengan demikian kita bisa belajar melalui strategi yang sebelumnya.Strategi tersebut harus sesuai dengan kebuhuhan yang diperlukan dalam perencanaan kurikulum.Jangan sampai strategi yang dilaksanakan keluar dari perencanaan yang telah direncanakan.

\section{c) Pengawasan dan Evaluasi Memungkinkan Untuk Perubahan Perencanaan}

Perencanaan pada kurikulum bisa mengalami perubahan.Perencanaan tersebut bisa diubah apabila perencanaan yang sebelumnya dibuat tidak sesuai dengan tujuan dan ketentuan dari kurikulum.Serta apabila perencanaan tersebut tidak tidak bisa terlaksana seluruhnya dan juga prencanaan memunkinkan untuk diubah.Maka pihak pengawas kurkulum bisa menyuruh untuk merubah perencanaan yang telah dibuat.Karena tidak sesuai dengan tujuan kurikulum.Perubahan ini harus lebih baik dari perencanaan sebelumnya, masa sangat diperlukan evaluasi untuk perubahan perencanaan kurikulum.Kita bisa belajar dari kesalahan sebelumnya melalui evaluaisi ini.Jika perencanaan kurikulum sudah sesuai dengan tujuan kurikulum maka tidak diperlukan perubahan perencaan, karena sudah sesuai dengan tujuan kurikulum.

\section{2) Pelaksanaan}

Pelaksanaan kurikulum disekolah dapat direalisasikan melaui proses belajar mengajar yang sesuai dengan prinsipprinsip dan tuntutan dari kurikulum yang telah dikembangkan sebelumnya bagi suatu program pendidikan. Pelaksanaan kurikulum tidak hanya pelaksanaan pada tingkat sekolah saja melainkan pelaksanaan pada tingkat kelas.Pada pelaksanaan tingkat sekolah yang berperan penting adalah kepala sekolah, namun berbeda dengan pelaksanaan tingkat kelas yang berperan bukanlah kepala sekolah melainkan guru mata pelajaran yang bersangkutan. Walaupun yang berperan dalam pelaksanaan kurikulum tingkat sekolah dan tingkat kelas itu berbeda namun dalam pelaksanaan kurikulum itu sendiri harus senantiasa berhubungan dan bertanggung jawab berasamasama dalam melaksanakan proses pelaksanaan kurikulum.

Pelaksanaan dalam kurikulum harus berdasarkan pada tahap-tahap berikut ini yaitu:

\section{a) Penyusunan Program Pengajaran Semesteran}

Tujuan penyusunan program pengajaran semesteran atau caturwulan ini adalah menjabarkan bahan pelajaran yang akan disajikan guru dalam proses belajar mengajar, mengarahkan tugas yang harus ditempuh guru agar pengajaran dapat dilakukan secara bertahap dan tepat, dan mengatur pelaksanaan proses belajar mengajar sesuai dengan banyaknya minggu efektif sekolah yang tersedia berdasarkan kalender pendidikan. Pelaksanaan kurikulum juga bisa dilakukan pada penyusunan program pengajaran semesteran, melalui pengajaran semesteran kita bisa mengetahui apakah kurikulum yang telah diterapkan pada sekolah tertentu bisa menaikkan kualitas pendidikan disekolah tersubut.Dengan demikian setiap sekolah bisa mengevaluasi tiap mata pelajaran yang diterapkan.Jika terdapat peningkatan dari nilai siswa maka kurikulum yang ditepkan tersebut bisa digunakan.Selebum pelaksaan kurikulum secara keseluruhan, kita harus melakukan uji coba dulu apakah kurikulum tersebut memang bisa diterapkan disekolah itu atau tidak.Maka sangat diperlukan uji coba terlebih dahulu. 


\section{b) Penyusunan Persiapan Mengajar}

Penyusunan persiapan mengajar yang akan digunakan dan dipedomani oleh guru dalam melaksanakan proses belajar mengajar di kelas. Sebelum seorang guru masuk kekelas untuk memulai proses pembelajaran maka sangat dibutuh kan persiapan pembelajaran seperti persiapan bahan ajar, media yang akan digunakan, atau alat bahan yang diperlukan dalam mengajar didalam kelas. Persiapan mengajar ini juga harus sesuai dengan kurikulum yang tersedia pada mata pelajaran masing-masing yang akan diajarkan oleh guru. Maka persiapan mengajar ini juga harus berdasarkan dari panduan kurikulum mata pelajaran.

\section{c) Pelaksanaan Proses Belajar Mengajar}

Proses belajar mengajar akan efektif apabila kurikulum yang digunakan oleh suatu sekolah tersebut bisa membentuk karakter dari masing-masing siswanya, selain itu juga dapat melaksanakan tujuan pendidikan dengan baik. Selain untuk membentuk karakter siswa kurikulum yang diterapkan tersebut harus bisa menaikkan mutu pendidikan disekolah tersebut. Sebelum proses belajar mengajar terlaksana seorang guru haru terlebih dahulu melakukan persiapan mengajar. Jika persiapan mengajar disusun secara baik, maka pelaksanaan proses mengajar juga bisa terlaksana dengan baik. Tahap proses mengajar ini sangat penting karena pada tahap inilah guru dan siswa bisa berinterkasi langsung. Dimana guru bisa mengetahiu karakter siswa melalui proses interaksi langsung ini. Maka untuk itu sekolah harus menerapkan kurikulam yang bagus agar interaksi yang terjadi antara siswa dan guru bisa berjalan dengan bagus juga. Dan pelaksanaan proses belajar mengajarpun akan terlaksanakan dengan baik juga.

\section{d) Kegiatan Kurikuler dan Ekstrakurikuler}

Selain kegiatan belajar dan mengajar didalam kelas siswa juga membutuhkan kegiatan ekstra kurikuler.Kegiatan ekstra kurikuler ini bertujuan untuk pengembangan bakat dari siswa maunpun siswi disekolah.Kegiatan kurikuler dan ekstrakurikuler juga sangat dibutuhkan siswa karena bisa mmenghilangkan sedikit kejenuhan siswa terhadap pelajaran yang diajarkan.Selain itu kegiatan ini juga bisa melatih siswa dalam bersosialisasi dan juga mempererat hubungan antar sekolah.Melalui pertandingan antar sekolah inilah bisa mengeratkan hubungan antar sekolah.

\section{3) Pengawasan}

Pengawasan identik dengan kata controlling yang berarti pemeriksaan.Sedangkan dalam kamus Bahasa Indonesia pengawasan adalah penilikan dan penjagaan, jadi pengawasan berarti mempertahankan dan menjaga dengan baik.Menurut winardi, pengawasan adalah semua aktivitas yang dilaksankan oleh pihak manajer dalam upaya memastikan bahwa hasil aktual sesuai dengan hasil yang direncanakan. Pengawasan adalah fungsi administratif bagi setiap administrator untuk memastikan bahwa apa yang dikerjakan sesuai dengan yang dikehendaki. Pengawasan itu meliputi pemeriksaan apakah semua berjalan sesuai dengan rencana yang dibuat, instruksi-instruksi yang dikeluarkan dan prinsip-prinsip yang ditetapkan (Sudjana, 2005).

Ketika kurikulum mulai diterapkan disekolah-sekolah maka perlu dilakukan pengawasan kurikulum. Proses pembelajaran yang dilakukan disekolah-sekolah akan diawasi, melalui pemantauan dari pengawas kurikulum. Pengawasan akan dilakukan secara berkala dan berlanjut. Pengawasan akan dilakukan pada guru yang melakukan proses pembelajaran dan pengawasan dapat dilakukan oleh kepala sekolah maupun pengawas itu sendiri. Selama melaksanakan pengawasan kepala sekolah maupun pengawas harus melaksanakannya dengan tujuan meningkatkan mutu proses pembelajaran guru dan untuk menetapkan peningkatan akreditasi. Kemudian hasil dari pemantauan itu akan dilaporkan di dinas pendidikan. Proses pelaporan harus memuat hasil-hasil dari kegiatan pemantauan hingga evaluasi proses pembelajaran. Pelaporan diberikan dalam bentuk laporan yang bertujuan untuk dilakukan tindak lanjut. Tindak lanjut dapat diberikan dengan cara memberi kesempatan kepada guru-guru tersebut untuk mengikuti program pelatihan guru.

\section{4) Evaluasi Kurikulum}

Evaluaisi ini dilakukan agar kita bisa melakukan perubahan kurikulum ke yang lebih baik untuk mencapai mutu pendidikan. Evaluisi dapat dilakukan dengan cara yaitu:

\section{a) Evaluasi Hasil Belajar}

Evaluasi hasil belajar merupakan suatu kegiatan yang dilakukan guna memberikan berbagai informasi secara berkesinambungan dan menyeluruh tentang proses dan hasil belajar yang telah dicapai siswa. Evaluasi hasil belajar ini bertujuan untuk untuk mengetahui peningkatan hasil belajar siswa, mengetahui tingkat keberhasilan proses belajar mengajar, dan untuk menentukan tindak lanjut dari hasil penilaian untuk siswa tersebut.

\section{b) Evaluasi Program Pengajaran}

Evaluasi program pengajaran merupakan suatu rangkaian kegiatan yang dilakukan dengan sengaja untuk melihat tingkat keberhasilan program, serta faktor-faktor yang mendukung atau menghambat keberhasilan program tersebut.Evaluasi program pembelajaran bertujuan untuk mengetahui pencapaian dari tujuan pembelajaran yang telah terlaksana.Hasil evaluasi ini akan digunakan sebagai dasar untuk melaksanakan tindak lanjut berikutnya. 


\section{Peranan Guru dalam Administrasi Pendidikan}

Personal pendidikan adalah golongan petugas yang membidangi kegiatan eduktif dan yang membidangi kegiatan non edukatif (ketatausahaan). Personel bidang edukatif adalah mereka yang bertanggung jawab dalam kegiatan belajar mengajar, yaitu guru dan konselor (BK)(Kosasi, 1994).

Di sekolah, guru berada dalam kegiatan administrasi sekolah.Sekolah melaksanakan kegiatannya untuk menghasilkan lulusan jumlah dan mutunya telah ditetapkan.Dalam lingkup administrasi sekolah inilah peran guru sangat penting. Dalam menetapkan kebijaksanaan dan melaksanakan proses perencanaan, pengkoordinasian, pengarahan, pengorganisasian, pembiayaan dan penilaian kegiatan kurikulum, kesiswaan, sarana dan prasarana, personalia sekolah, keuangan dan hubungan sekolah dengan masyarakat(Asnawir, 2004)

Guru merupakan orang yang akan membangun motivasi belajar dan meningkatkan suatu pendidikan. Guru bukan hanya berperan sebagai pengajar, namun juga berperan sebagai pendidik. Guru tidak hanya melakukan kegiatan mengajar saja, namun guru juga berperan dalam administrasi kurikulum. Karena semua guru memiliki tujuan yang sama yaitu untuk mensukseskan pendidikan dan menciptakan generasi yang berkualitas, tidak hanya dalam segi prestasi namun juga dalam membentuk karakter siswa.

\section{KESIMPULAN}

Administrasi kurikulum merupakan seluruh proses kegiatan yang direncanakan dan diusahakan secara sengaja dan bersungguh-sungguh serta pembinaan secara continue terhadap situasi belajar mengajar secara efektif dan efisien demi membantu tercapainya tujuan pendidikan yang telah ditetapkan. Administrasi kurikulum bertujuan untuk meningkatkan efektivitas kinerja guru maupun siswa dalam mencapai tujuan pembelajaran, pengelolaan kurikulum yang profesional, efektif dan terpadu. Guru memili peran yang sangat penting dalam administrasi kurikulum, selain untuk menciptakan generasi yang cerdas, namun guru juga berperan dalam pembentukan karakter siswa. Jadi kegiatan dalam administrasi kurikulum adalah berbagai kegiatan yang bertujuan untuk melaksanakan dan mengembangkan kurikulum sehingga kurikulum dapat dijadikan sebagai instrument dalam mencapai tujuan dan sasaran pendidikan. Dengan menerapkan prinsip-prinsip administrasi kurikulum kemudian dikembangkan sehingga dalam pelaksanaannya kurikulum dapat mencapai sasaran pendidikan yang diharapkan.

\section{Daftar Pustaka}

(UU. No.20 tentang Sistem Pendidikan Nasional. , Pub. L. No. No. 20 (2003).

Afriyansyah, H. (2019). Administrasi Kurikulum. Retrieved from https://doi.org/10.17605/OSF.IO/Y6VXZ

Asnawir. (2004). Administrasi Pendidikan. Padang: IAIN IB Press.

Daryanto. (2011). Administrasi Pendidikan. Jakarta: Rineka Cipta.

Kosasi, S. \& R. (1994). Profesi Keguruan. Jakarta: P3TK Depdikbud.

Sudjana. (2005). Pembinaan dan Pengembangan Kurikulum di Sekolah. Jakarta: Sinar Baru Algesindo.

Suryosubroto, B. (2004). Manajemen Pendidikan. Jakarta: Rineka Cipta. 